\title{
AMBITION THEORY AND THE BLACK POLITICIAN
}

\author{
Pauline Terrelonge Stone \\ University of Michigan
}

$\mathrm{O}$ WING to the seminal work of Joseph Schlesinger, ${ }^{1}$ the study of political ambitions has achieved a place of prominence in the political science literature as students of political leadership have come to recognize that the topic provides valuable insights into the dynamics of elite political behavior. Despite the fact that many of the propositions derived from Schlesinger's work have been tested in a diversity of empirical contexts ${ }^{2}$ national, state and local - and among various types of political figures including members of Congress, state executives, prosecuting attorneys, state legislators and city councilpersons - there are several deficiencies apparent in the extant literature.

Some of these stem from Schlesinger's original conceptualization of the nature of political ambitions. Most strikingly, the etiology of political ambitions receives little consideration in his analysis, an outcome of the central place that he ascribes to the political opportunity structure in the genesis of divergent office goals. While the effect of systemic, structural factors should not be negated as critical causative factors underlying differentiation in political ambitions, it is myopic if not simplistic to place total emphasis on them to the neglect of other social and political factors since human motivations are complex and generally subject to a multiplicity of stimuli.

The need to take a multi- rather than unicasual approach in the study of political aspirations is especially pertinent with regard to black officeholders; for one, we know very little about this aspect of black elite behavior. Furthermore, though a profound change is apparently taking place in the black opportunity structure, merely to assume ${ }^{3}$ that blacks will vary in their ambitions because some offices are more pervious to their access than others will result in only partial insights into the nature of intra-group variation in the political ambitions of black officeholders.

In attributing almost total importance to the structure of political opportunities as the cause of differentiation in political ambitions, Schlesinger's work also is wanting in the restriction of its focus to the political consequences of political ambitions. While such an emphasis is valuable for understanding the output side of elite political behavior, it is insufficient; equally important is the input side: the causes or sources of ambitions. Unfortunately most empirical

\footnotetext{
${ }^{1}$ Joseph Schlesinger, Ambition and Politics: Political Careers in the United States (Chicago: Rand McNally, 1966).

${ }^{2}$ See for example, Gordon Black, "A Theory of Political Ambitions: Career Choices and the Role of Structural Incentives," American Political Science Review 66 (March 1972): 144-59; William H. Dutton, "The Political Ambitions of Local Legislators: A Comparative Perspective," Polity 8 (Summer 1975): 504-22; Richard L. Engstrom, "Political Ambitions and the Prosecutorial Office," Journal of Politics 33 (February 1971): 190-94; Jeff Fishel, "Ambition and the Political Vocation: Congressional Challengers in American Politics," Journal of Politics 33 (February 1971): 25-56; Paul L. Hain, "Age, Ambition, and Political Careers: The Middle-Age Crisis," Western Political Quarterly 27 (June 1974): 265-74; Kenneth Prewitt and William Nowlin, "Political Ambitions and the Behavior of Incumbent Politicians," Western Political Quarterly 22 (June 1969): 298-308; Kenneth Prewitt, "Political Ambitions, Volunteerism, and Electoral Accountability," American Political Science Review 64 (1970): 5-18; John W. Soule, "Future Political Ambitions and the Behavior of Incumbent State Legislators," Midwest Journal of Political Science 13 (August 1969): 439-54; E. Nelson Swinerton, "Ambitions and American State Executives," Midwest Journal of Political Science 12 (November 1968): 538-49; William N. Thompson, "An Analysis of the Legislative Ambitions of State Constitutional Convention Delegates," Politics and Society 6 (1976): 425-39.

${ }^{3}$ Schlesinger's statement that the opportunity structure influences ambitions is not stated in the form of an empirical proposition but as an axiom-i.e., it is not subject to verification.
} 
work that has probed the validity of Schlesinger's propositions has largely followed in his footsteps, ${ }^{4}$ failing to recognize that it is just as crucial to explain the causes of any political phenomenon as the consequences.

Another characteristic of the empirical literature on political ambitions is its preoccupation with the ambitious political figure - that is, those desirous of election to the same or higher office - to the neglect of the unambitious, or what Schlesinger refers to as those with discrete ambitions. This paper is particularly interested in the latter group because we believe that knowledge of the types of blacks who are "turned off' from pursuing a political career, as well as those who continue to be attracted, can reveal a great deal about the black recruitment process and the future shape of the black political elite.

This paper attempts to address these deficiencies in the literature on political ambitions. First of all, it asks the heretofore unexplored question: Is there a range of political ambitions among black public officeholders as there is among other public servants? This is a question that should be subject to empirical investigation and not taken for granted: It is quite possible, particularly in view of the relatively improved electoral opportunities that have recently opened up to blacks, that practically all blacks are politically ambitious and that there is little range in their office goals. If black public officials are indeed monolithic in terms of their political ambitions, this could yield dire political consequences because it could result in a noncirculating or nonaccountable black political elite. ${ }^{5}$

On the other hand, the possibility looms large that a significant proportion of black politicians will not harbor any upward political aspirations for their largest concentrations are in local office ${ }^{6}$ and previous research - conducted on white politicians - has shown that local officeholding is commonly associated with amateurish rather than careerist political orientations. ${ }^{7}$

The second part of this paper is devoted to unravelling the possible causal antecedents or sources of black political ambitions. While mindful of the pitfalls of background studies, ${ }^{8}$ it is important to inquire whether blacks with similar political and social histories also bear similarities in terms of their willingness to advance politically.

4 These studies have mainly been concerned with the relationship between political ambitions and attitudes. See for example, Prewitt and Nowlin, "Political Ambitions of Incumbent Politicians"; Soule, "Future Political Ambitions"; Swinerton, "Ambitions and American State Executives"; and Engstrom, "Political Ambitions." One study that considered both the sources and consequences of political ambitions is Fishel's "Ambition and the Political Vocation."

${ }^{5}$ For a discussion of the role of ambitions in maintaining electoral accountability see Schlesinger, Ambition and Politics; Prewitt, "Political Ambitions and Electoral Accountability"; and Dutton, "Political Ambitions of Local Legislators."

${ }^{6}$ In 1975 the total number of black elected officials amounted to 3,979; 1889 of these were located at the municipal level and 315 at the county level. National Roster of Black Elected Officials, Vol. 6, August 1976 (Washington, D.C.: Joint Center for Political Studies).

${ }^{7}$ See for example, Prewitt, "Political Ambitions and Electoral Accountability"; Dutton, "Political Ambitions of Local Legislators."

${ }^{8}$ Schlesinger criticizes background studies on two counts: one, because they have failed to produce predictive propositions about behavior; secondly, because they tend to eliminate the political dimension from behavior. While these criticisms bear some validity, we believe that certain aspects of political leadership-e.g., political recruitment and socialization-other than the behavioral aspects can be illuminated by an examination of social and political backgrounds. For further discussion of the utility of "background studies" see Herbert Jacob, "Initial Recruitment of Elected Officials in the United States: A Model," Journal of Politics 24 (November 1962): 703-16; Moshe M. Czudnowski, "Sociocultural Variables and Legislative Recruitment," Comparative Politics (July 1972): 561-87; William Quandt, The Comparative Study of Political Elites (Beverly Hills: Sage Professional Papers in Comparative Politics, 1970); Lewis Edinger and Donald Searing, "Social Background in Elite Analysis: A Methodological Inquiry," American Political Science Review 61 (June 1967): 428-45; Schlesinger, Ambition and Politics, pp. 12-16. 


\section{METHOD OF INQUIRY}

Data for this study are taken from a 1974 random survey of 119 blacks holding elective office in Michigan at all rungs of the office hierarchy - federal, state, county, municipal, and township - and in all sectors of government executive, legislative, judicial, educational, and administrative. The sample was chosen from a population universe of 180 black elected officials. ${ }^{9}$

To ascertain the extent of differentiation in the political ambitions of the sample, these officeholders were asked a series of questions ${ }^{10}$ about their future political aspirations, and their responses were coded into three categories: progressive, static, and discrete. Conforming to Schlesinger's original typology, a progressively ambitious politician aspires for an office that is higher in political status than the one he/she presently holds; an officeholder with static ambition seeks to remain in public office but does not intend to run for a higher post; finally, the discretely ambitious politician sees no future role in politics and has decided to abandon his/her quest for elective office. ${ }^{11}$

\section{FINDINGS}

The first task of this analysis is to discover the extent of divergence in the political ambitions of black officeholders. Showing that the black politician is not a political animal sui generis, the data reveal that a range of ambitions is to be found among black elected officials as among other political figures. While a majority aspire for either the same (35 percent) or higher office ( 39 percent), a significant minority (26 percent) are uninterested in reelection; ${ }^{12}$ the fact that one-quarter of the sample is unambitious is quite significant because it ensures that there will be electoral turnover among black officeholders, although it may suggest a low degree of accountability. Before proceeding to an examination of the way in which the political ambitions of the politically ambitious and unambitious diverge in terms of their social and political backgrounds, let us first examine the specific offices held by, and the office goals of, the ambitious.

Contrary to what one might expect, officeholders with progressive ambitions are not motivated to seek higher office by virtue of having experienced low political status, for higher office is not always sought by the most politically disadvantaged. Rather the data show that upper level offices ${ }^{13}$ have a higher proportion of officeholders with progressive ambition than do lower level offices. The same pattern is observable among officeholders with static ambitions; however, the reverse is true for those with discrete ambitions. As office level increases the higher the proportion of officeholders with static ambition, and the lower the proportion with discrete ambition. These findings seem to lend some support to Schlesinger's dictum that the office structure influences

${ }^{9}$ These officeholders were, with a few exceptions, identified from the 1974 edition of the National Roster of Black Elected Officials.

10 The following questions were asked to get at the political ambitions of the sample:

A. Do you intend to run for office again?

B. If so, when will you run, in the near future or in the distant future?

C. Which office would you like to run for most?

D. Why do you intend to run for this office?

11 This measure of political ambitions may be treated as nominal or ordinal; when used as the latter, a progressive ambition is considered to be the highest level of ambition, discrete the lowest, and a static ambition the intermediate.

12 The fact that one-quarter of the sample falls into the discrete category is somewhat unique as Prewit and Dutton report percentages of 18 and 6 in their studies of public officials in San Francisco and Buffalo respectively. See Prewitt, "Political Ambitions and Electoral Accountability"; and Dutton, "Political Ambitions of Local Legislators."

${ }^{13}$ Level of office is operationalized in terms of formal governmental structure, i.e., federal, state, county, municipal. 
the direction of political ambitions; the ambitious clearly have profited more from office-holding than the unambitious, and this may partly explain their continued attraction to public life.

Because limiting our focus only to the level of office held by officeholders could serve to cloud differences in the type of offices held, it is valuable to examine the distribution of the three ambition types among different categories of office. As shown by Table 1, officeholders with progressive ambitions are most likely to hold legislative office, and to a lesser extent executive; statics similarly converge in legislative, but are also well represented in executive and judicial office. In contrast to the preceding patterns, discretes are less well represented in legislative or judicial office, but instead predominate in the educational category. This concentration of the unambitious in educational posts is quite understandable. Most of these offices are on the school board, positions that are rarely embarked on because of a strong commitment to professional politics but more commonly out of a sense of civic duty, hence ones not noted to be important political steppingstones. Significantly, very few of the unambitious hold judicial office; this is not surprising since judicial office ranks high in terms of prestige, salary, and length of tenure, factors which would probably render these offices very attractive to most public officials.

TABle 1. Political Ambitions and Type of Office Held

\begin{tabular}{|c|c|c|c|}
\hline \multirow[b]{2}{*}{ Type of Office } & \multicolumn{3}{|c|}{ AMBITION TYPE } \\
\hline & Progressive & Static & Discrete \\
\hline 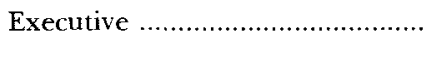 & $\begin{array}{c}19.6 \\
(9)\end{array}$ & $\begin{array}{c}19.0 \\
(8)\end{array}$ & $\begin{array}{c}19.4 \\
(6)\end{array}$ \\
\hline 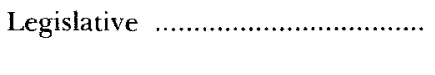 & $\begin{array}{c}39.1 \\
(18)\end{array}$ & $\begin{array}{c}38.1 \\
(16)\end{array}$ & $\begin{array}{c}25.8 \\
(8)\end{array}$ \\
\hline Judicial & $\begin{array}{c}15.2 \\
(7)\end{array}$ & $\begin{array}{c}21.4 \\
(9)\end{array}$ & $\begin{array}{l}3.2 \\
\text { (1) }\end{array}$ \\
\hline 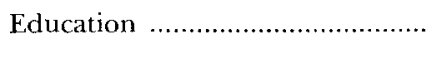 & $\begin{array}{c}15.2 \\
(7)\end{array}$ & $\begin{array}{l}7.2 \\
(3)\end{array}$ & $\begin{array}{l}38.7 \\
(12)\end{array}$ \\
\hline Administrative & $\begin{array}{l}10.9 \\
(5)\end{array}$ & $\begin{array}{l}14.3 \\
(6)\end{array}$ & $\begin{array}{c}12.9 \\
(4)\end{array}$ \\
\hline TOTAL $\ldots \ldots \ldots \ldots \ldots \ldots \ldots \ldots \ldots \ldots \ldots \ldots \ldots \ldots \ldots \ldots$ & $\begin{array}{c}100 \% \\
(46)\end{array}$ & $\begin{array}{c}100 \% \\
(42)\end{array}$ & $\begin{array}{c}100 \% \\
(31)\end{array}$ \\
\hline
\end{tabular}

When we examine the precise offices aspired to by officeholders with static and progressive ambitions, we get a clearer picture of the offices which are most attractive to black officeholders. The offices that are most desirable based on the percentages of officeholders desiring them, are mayor, congressman, and state representative: nearly three-fifths of the sample aspire to one of these three offices, roughly one-fifth to each. Almost equally attractive are judgeships and state senatorial positions.

There are two ways to assess whether these office goals are realistic. One would be to compare the individual's qualifications with the demands of the office desired. Unfortunately, apart from knowing that judgeships require a law degree, we lack the data to make such a comparison. The second approach that we can use to evaluate whether the political ambitions of this group are practical is to compare the offices aspired to with those currently held. Such a comparison reveals a wide discrepancy (Table 2) suggesting that the office aspirations of these black elected officeholders are not congruent with past success in achievement. For example, although less than 1 percent of the sample holds congressional office, nearly one-fifth of the officeholders are interested in running for this particular office; only about 2.5 percent are state 
TABLE 2. Office Goals and Offices Held by Officenolders With Progressive Ambitions

\begin{tabular}{|c|c|c|}
\hline Office* & $\begin{array}{l}\text { \% of Sample } \\
\text { Aspring to }\end{array}$ & $\begin{array}{c}\% \text { of Sample } \\
\text { Holding }\end{array}$ \\
\hline Mayor .............. & 21.7 & 5.0 \\
\hline 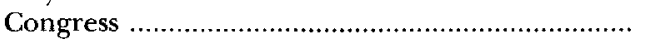 & 17.4 & .8 \\
\hline 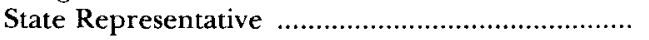 & 17.4 & 13.5 \\
\hline Judge & 15.2 & 12.6 \\
\hline 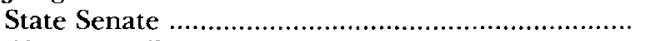 & 13.0 & 2.5 \\
\hline 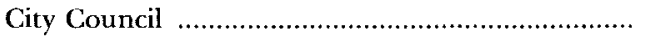 & 6.5 & 23.5 \\
\hline 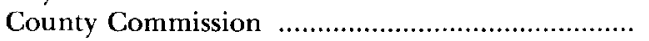 & 2.3 & 8.4 \\
\hline 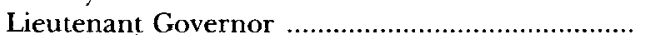 & 2.2 & 0.0 \\
\hline 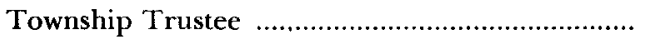 & 2.2 & 5.0 \\
\hline TOTAL & $100 \%$ & $71.3 \% \dagger$ \\
\hline
\end{tabular}

* Ranked in order of preference.

† Only 71.3 percent or 90 members of the sample held an office that was considered desirable by those with progressive ambitions.

senators but 13 percent crave to ascend to these positions; finally, a mere 5 percent hold the office of mayor, yet one-fifth aspire to this position.

Judgeships and the lieutenant governorship are the only two offices where office aspirations are somewhat in line with the reality of past attainment: Only 2 percent of the sample long for the office of lieutenant governor, a fact which is understandable since no black in Michigan has ever held this position, nor up to the time of the survey had a black ever been nominated for it. The amount of interest in a seat on the bench is also congruent with past black successes in the judicial realm: about 13 percent of the officeholders in the sample hold one of these positions and 15 percent are considering seeking election to them. Perhaps the closer correlation here between aspirations and past attainment is a function of the fact that to be a judge one needs to be trained in the law, and only 17 percent of the sample have a legal background. ${ }^{14}$ If the qualifications for judgeships were less selective, possibly those desiring these offices would significantly exceed those holding them, as is the case with most of the other offices.

\section{The Social and Political Correlates of Black OFFICEHOLDERS' AMBITIONS}

Having examined the career choices of black public officials, let us now turn our attention to the factors that may be the underlying source of the observed differentiation in ambitions. Two sets of factors are hypothesized to be critical to the explanation of variations in political ambition: political experience, and social group membership. By looking at the relationship between these factors and political ambition, hopefully we will discover whether black officeholders' office goals are randomly distributed or conversely, whether they are a function of where they came from, the groups-both ascriptive and achieved-to which they belong, or the social and political routes along which they have traveled to office.

\section{Political Experience: Partisan and Governmental}

The political experience of public officeholders may be divided into two types: partisan and governmental. At first blush one might expect officeholders with discrete ambitions to be lacking in both these types of political experience.

14 The low proportion of lawyers in the sample is unique in the American context. It suggests that black politicians may exhibit distinct motivational patterns in comparison to their white counterparts, and indeed, may be different policical animals altogether. 
Of course this may not prove true. It would be the case only if officeholders with this type of ambition regarded politics as an avocation rather than a vocation. On the other hand, it is highly possible that the disinterest of some officeholders in continuing their public office careers stems from a feeling that having paid their dues-that is, having been politically involved and having acquired the requisite experience-they have not gained the rewards that normally follow from their political involvements. If the latter is the case, our data should show officeholders with discrete ambitions having political experiences similar to those of officeholders with static and progressive ambitions. To ascertain whether this is indeed the case, we will look at several indices of political involvement.

A critical dimension of political activity would seem to be political party indentification since generally in political life, political party identifiers are more prone to be political participants than non-identifiers. ${ }^{15}$ The proposition that officeholders who consider themselves to be independents would be less politically ambitious than party affiliates is supported by our data. Nearly half of the self-proclaimed independents had discrete ambitions compared to onequarter of the Democratic and none of the Republican affiliates (Table 3). As a group then, independents are less likely to be found in the ranks of the politically ambitious than Democrats or Republicans, and the latter more so than the former. Because all women in the sample are Democrats, there is no difference in party membership among women officeholders with varying ambitions, although there is a significant difference among men.

Table 3. Political Ambitions and Political Party Affiliation

\begin{tabular}{|c|c|c|c|}
\hline Type of Ambition & Democratic & Republican & Independent \\
\hline \multirow[t]{2}{*}{ 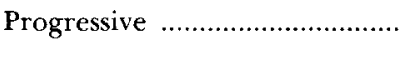 } & 38.0 & 58.3 & 26.7 \\
\hline & $(35)$ & $(7)$ & (4) \\
\hline \multirow[t]{2}{*}{ Static } & 35.9 & 41.7 & 26.7 \\
\hline & $(33)$ & $(5)$ & $(4)$ \\
\hline \multirow[t]{2}{*}{ Discrete } & 26.9 & 0.0 & 46.7 \\
\hline & $(24)$ & $(0)$ & $(7)$ \\
\hline \multirow[t]{2}{*}{ TOTAL $\ldots \ldots \ldots \ldots \ldots \ldots \ldots \ldots \ldots$} & $100 \%$ & $100 \%$ & $100 \%$ \\
\hline & (92) & $(12)$ & (15) \\
\hline
\end{tabular}

Although political party membership is significantly associated with political ambitions, not all experiences with political parties lead to greater ambitions. To illustrate: officeholders who have held a political party office are no more likely to have progressive or static ambitions than discrete ambitions. Similarly, there is no relationship between one's ambition and the degree of personal involvement in political party organizations; however, when sex is taken into account a relationship emerges. Among males, officeholders with progressive and static ambitions more often report a close relationship to a political party than discretes. Among females, the reverse pattern persists: a much higher proportion of women with close party relationships are found in the discrete than in the static or progressive categories. This sexual difference suggests that men who decide to exercise the exit option from public officeholding may have been prompted to do so because of the absence of a close personal relationship to a political party and exclusion from the attendant political resources which such a relationship can offer. Conversely, a close political party relationship is no guarantee that a woman will continue to pursue

${ }^{15}$ Angus Campbell et al., The American Voter (New York: Wiley, 1960), pp. 120-67; William H. Flanigan and Nancy Zingale, Political Behavior of the American Electorate (Boston: Allyn and Bacon, 1975). 
a political career, a fact which suggests that close party relationships are less rewarding to women in realizing their office goals than they are for men. This is highly likely to be the case since the literature on political parties has consistently revealed that women, though generally comprising the overwhelming portion of political partyworkers, are less often found in the higher echelons of political party organizations and are less likely to receive political party nominations than men. ${ }^{16}$

Given the fact that some dimensions of political party experience are associated with differential political ambitions, one might expect to find a significant relationship between straight-ticket voting and political ambitions. Oddly, this is not so. Ambition and straight-ticket voting are inversely related: progressives are more likely to split their tickets between parties than statics, and both more than discretes. Thus officeholders bent on achieving higher office or maintaining that which they have already achieved seem to have a more pragmatic approach to partisan concerns than those without future office goals. However, this pattern is not found among all officeholders, but is sexually specific. Among females, ambition is in no way related to whether one votes a straight ticket or not, whereas a relationship exists among the male subsample. So ambitious male officeholders are more "political" than ambitious females in that the ambitious male is more likely than the ambitious female to have a close personal relationship to a political party, to split his vote, and to be Republican. ${ }^{17}$

Like partisan experience, only certain aspects of governmental activity are associated with political ambitions. Attesting to this convergence, officeholders with discrete ambitions have not held political appointments, run for public office, or spent time in elective office to any less extent than their more ambitious counterparts. In only one aspect of governmental activity are discretes more inexperienced vis-à-vis other officeholders-the number of elective offices which they have held. This, of course, is a critical area in which to be politically inexperienced for the number of offices one has held can have a direct bearing both on type of upward career mobility one can expect, and the type and level of office one holds at any given point in time.

\section{Mode of Political Recruitment}

Since an array of agents is commonly responsible for launching politicians' public careers, and some-like political parties and labor organizations-are able to offer valuable resources, both material and symbolic, that can make the difference between winning and losing an election, logic suggests that the way in which a politician was recruited for office would influence his/her political ambitions. In view of the greater personal resources that must be expended when no external assistance is available to a political candidate, it would seem reasonable that the self-recruited would be less ambitious for public office than the sponsored. This line of reasoning, however, is not borne out by the data. In fact, the reverse is true. As ambition increases so does the likelihood than an

\footnotetext{
${ }^{16}$ See, inter alia, Maurice Duverger, The Political Role of Women (Paris: UNESCO, 1955), pp. 145-50; Edmond Constantini and Kenneth H. Craik, "Women as Politicians: The Social Background, Personality and Political Careers of Female Party Leaders," Journal of Social Issues 28 (1972): 217-36; Gabriel Almond and Sydney Verba, The Civic Culture (Boston: Little, Brown, 1965), p. 333; M. Kent Jennings and Norman Thomas, "Men and Women in Party Elites: Social Roles and Political Resources," Midwest Journal of Political Science 12 (1968): 472. Margueritte Fisher, "Women in Political Parties," Annals 251 (May 1947): 87-93.

${ }^{17}$ Although most researches have also found women politicians to be more ardent party loyalists than men, Kirkpatrick's recent study of the 1972 national convention delegates failed to find support for this pattern. Jeane Kirkpatrick, The New Presidential Elite (New York: Russell Sage, 1976), p. 434.
} 
official's career has been self-initiated. Although motivation for seeking higher office or retaining the same is lower among the sponsored, nonetheless, some types of sponsorship are more characteristic of the ambitious than the unambitious. Among officeholders with discrete ambitions, the most common agent of office sponsorship was community members rather than more explicitly political recruiters such as political parties or labor unions. Far more important than the community in the sponsorship of officeholders with static and progressive ambitions were incumbents already holding public office. Labor unions and political parties were of lesser significance in these two groups of officeholders' decisions to pursue a public career, though they were not any less significant than the community.

In sum then, the evidence so far has shown that the sharpest contrast with respect to political backgrounds among black officeholders with static, progressive and discrete ambitions, is between the two former on the one hand and the latter on the other. Willingness to stay in governmental office is much more characteristic of the politically experienced than the non-experienced. The relative political deprivation of the discretes leads us to ask whether this group of officeholders also comes from socially distinct backgrounds, since the social history of a group commonly affects its political potentialities and its aspirations.

\section{Personal and Social Background}

A priori, four dimensions would appear to be likely sources of differential ambitions among public officeholders: sex, age, maritial status, and socioeconomic status. ${ }^{18}$

Sex

One does not have to be a self-conscious feminist to recognize that one's sexual identity can serve to hinder or facilitate one's political career. Since political career success and sexual group membership are so closely related, one would expect women to be less ambitious for public office than men. Contrary to these expectations, however, there is no significant difference in the proportions of men and women with progressive, static or discrete ambitions. This is very surprising since Kirkpatrick found very stark sexual differences in political ambitions among the 1972 delegates to the national convention, although she failed to report whether these patterns also obtained among the black delegates. ${ }^{19}$

The similarity in the level of ambitions of male and female officeholders is further surprising because the women in the sample are much more disadvantaged than men in terms of their social and political backgrounds. In terms of social status, the level of educational and occupational status of female officeholders is well below the males'; oddly enough, their discrepant social statuses have no bearing on their level of ambitions. Male officeholders with progressive, static and discrete ambitions are no different from female officeholders in each of these three ambition categories with respect to their educational and occupational attainments.

However, crucial political disadvantages afflict women more than men and these are responsible for women with ambitions similar to those of men being quite unlike them in terms of political background. A look at office characteristics clearly exemplifies this point. With regard to distribution in part-time vs. full-time office, for example, women who exhibit static and progressive

\footnotetext{
${ }^{18}$ The reasons why we view these four factors as probable correlates of political ambition are explicated below in the separate discussion that is given to each of them.

${ }^{19}$ Kirkpatrick, New Presidential Elite, pp. 410-13.
} 
ambitions are much more likely than men with the same ambitions to hold part-time positions. Only in the discrete category do we find equal proportions of both sexes in part-time office, a fact which suggests that the decision of both sexes to leave office springs from similar motives: it could either be that office-holding has been less rewarding than it could have been or that amateurish motives underlay their initial decision to enter public life.

The fact that women who share similar ambitions with men have not achieved commensurate political success is underscored when a sexual comparison is made of the level and type of offices held. As shown by Table 4, most of the men with progressive ambitions hold legislative, executive, or judicial office; no woman with this level of ambition holds the latter type of office, but their representation in legislative and executive office is not significantly less than that of men. However, one-third of female progressives are currently located in educational offices which, as was noted earlier, are neither politically significant nor monetarily remunerative positions. Relative deprivation in officeholding may therefore account for the female officeholder's upward mobility aspirations.

TABle 4. Political Ambitions, Sex and Type of Office Held

\begin{tabular}{|c|c|c|c|c|c|c|}
\hline \multirow[b]{2}{*}{ Type of Office } & \multicolumn{3}{|c|}{ MaLes } & \multicolumn{3}{|c|}{ Females } \\
\hline & Pro. & Stat. & Dis. & Pro. & Stat. & Dis. \\
\hline \multirow[t]{2}{*}{ Executive } & 18.9 & 22.9 & 20.0 & 22.2 & 0.0 & 16.7 \\
\hline & (7) & $(8)$ & (5) & $(2)$ & $(0)$ & (1) \\
\hline \multirow[t]{2}{*}{ Legislative } & 40.5 & 40.0 & 28.0 & 33.3 & 28.6 & 16.7 \\
\hline & $(15)$ & (14) & $(7)$ & (3) & $(2)$ & (1) \\
\hline \multirow[t]{2}{*}{ Judicial ....................... } & 18.9 & 25.7 & 4.0 & 0.0 & 0.0 & 0.0 \\
\hline & $(7)$ & (9) & (1) & $(0)$ & $(0)$ & $(0)$ \\
\hline \multirow[t]{2}{*}{ Educational } & 10.8 & 8.6 & 44.0 & 33.3 & 0.0 & 16.7 \\
\hline & $(4)$ & (3) & (11) & $(3)$ & $(0)$ & (1) \\
\hline \multirow[t]{2}{*}{ Administrative ............. } & 10.8 & 2.9 & 4.0 & 11.1 & 71.4 & 50.0 \\
\hline & (4) & (1) & (1) & (1) & $(5)$ & (3) \\
\hline \multirow[t]{2}{*}{ TOTAL } & $100 \%$ & $100 \%$ & $100 \%$ & $100 \%$ & $100 \%$ & $100 \%$ \\
\hline & $(37)$ & $(35)$ & $(25)$ & (9) & (7) & (6) \\
\hline
\end{tabular}

Additional weight for this line of reasoning is provided by the fact that none of the females with static ambitions holds educational office. Nonetheless, women with static ambitions appear to have settled for different offices than men; they are disproportionately concentrated in administrative office, while the male officeholders with static ambitions hold either legislative ( 40 percent), executive (23 percent), or judicial office (26 percent).

Among officeholders with discrete ambitions sexual differences in type of office held are also marked. Most of the women who fall in this ambition category are in administrative office compared to only 4 percent of the men: the latter group overwhelmingly hold educational office. Since neither of these types of offices-educational or administrative-are highly ranked in the office hierarchy, this provides additional evidence for the view that dissatisfaction with holding politically insignificant offices is the underlying motive for the decision of both male and female officeholders to withdraw from office.

These sexual differences in the type of offices held by men and women with the same levels of ambition are underscored when attention is focused on the level of offices held. Most of the women with static ambition are located in municipal-level office ( 86 percent) compared to slightly less than half the men with the same ambitions. No woman with static ambition holds a county or federal office, and only one-sixth hold a state-level office. This contrasts starkly with male statics, one-quarter of whom hold county and state level offices 
respectively, and 3 percent of whom hold federal level offices. When we turn to those with progressive ambitions, a similar pattern emerges: women are overly concentrated in municipal office while men are more evenly distributed in the office hierarchy. Underscoring what was found earlier, the only ambition type where the sexes resemble each other in terms of the level of office they hold is the discrete. Both men and women with discrete ambition overwhelmingly hold municipal office.

Since positions vary in authority and, as a result, in the duties that must be performed, it would seem natural that offices higher up on the governmental ladder would require greater amounts of time and commitment from those who held them. Given female responsibility for familial concerns in our culture, it would be valuable to discover if the office aspirations of women are in any way tied to their marital status. Unfortunately, the sparsity of women in the upper levels of the office hierarchy precludes adequate examination of this topic. Nonetheless we can arrive at a notion of whether the relationship between the location of women in the office hierarchy and their office aspirations is affected by their marital status by focusing on men and women in municipal office.

All the women in city government who have static and discrete ambitions are married in contrast to only 50 percent of those who have progressive ambitions. Similarly, men at the municipal level are also highly likely to be married if they have static and discrete ambitions: their percentages in each of these latter categories are 96 and 100 respectively. But while four-fifths of the men with upward office aspirations are married, only half of the women are. So not only are women with progressive ambitions significantly less likely to be married than women with static and discrete ambitions, but they are also less likely to be married than men who share their ambitions. Thus the reason why married women may be more satisfied with municipal office than nonmarried women is that municipal office is less likely to make such demands on them as conflict with their role in their homes and families.

In light of the foregoing differences in the office characteristics of male and female officeholders with similar types of ambitions, one would expect that the financial remuneration attendant to offices held would also be differentially associated with political ambitions. We should expect those with discrete ambition to be profiting less from officeholding than those with static or progressive ambitions, and the former more than the latter. This generalization is in the main true, but it breaks down when sex of officeholders is taken into account. Among men, those with discrete ambition are indeed more likely to be unsalaried than those with static and progressive ambitions. Among women, however, this pattern is mutated in two respects. First of all, women with progressive ambitions are much more likely than male progressives to receive no salary from office, a fact which suggests that female upward aspirations are not as circumscribed by the deprivations which they face as are men's. Indeed, deprivation may be the source of these women's desire to move up the career ladder. Further substantiation for this point of view is offered by the fact that whereas men with static and progressive ambitions both tend to earn salaries from office, women with progressive ambitions are much less likely to do so than women with static ambitions. This again suggests that women who have upward office goals are motivated, at least partially, by the fact that currently they are not receiving the expected rewards from officeholding.

Just as interesting as the sexual differences between male and female officeholders with similar ambitions in regard to the type and level of offices which they hold, are the differences in the offices to which they aspire (Table 5). Four salient differences mark the office aspirations of male and female officeholders. First of all, male office goals are more widely distributed than those of females. Secondly, no woman aspires to be elected to a judgeship, while 
nearly one-fifth of the men do. This may be explained by the fact that women in the sample all lack the necessary formal credential for becoming a judge, namely a law degree. Another interesting difference in the offices aspired for by men and women is that over half of the women desire two positions, that of mayor and state senator. Neither of these offices was ever held by any female in the sample, or for that matter, by a black woman in the entire state of Michigan (at least up until the time of the survey). Finally, about twice as many women as men aspire to the city council and to the state senate. In some respects then, women's goals seem somewhat utopian. Their aspirations for the city council and township trusteeship are not unrealistic since these are positions which women seem to have had fewer problems in winning up to now. However, their goals of becoming congresswomen, mayors, and state senators appear to be long-shots, because the record of women generally - and black women in particular - securing election to these positions in the past history of Michigan politics is dismal. These black women seem to be either oblivious to, or undeterred by the fact that in the arena of public policy-making there are two types of jobs - male jobs and female jobs.

TABle 5. Sex and Office Goals of Officeholders With Progressive Ambitions

\begin{tabular}{|c|c|c|}
\hline Office & $\begin{array}{c}\text { Males } \\
\% \text { Aspiring }\end{array}$ & $\begin{array}{c}\text { Females } \\
\text { \% Aspiring }\end{array}$ \\
\hline Mayor & 18.9 & 33.3 \\
\hline Congress & 18.9 & 11.1 \\
\hline 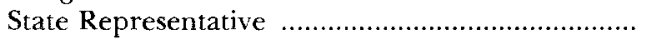 & 18.9 & 11.1 \\
\hline Judge & 20.8 & 0.0 \\
\hline 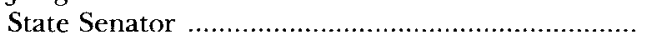 & 10.8 & 22.2 \\
\hline 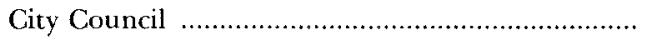 & 5.7 & 11.1 \\
\hline 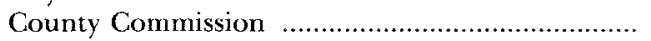 & 2.9 & 0.0 \\
\hline 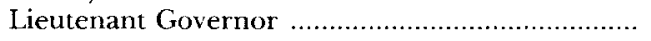 & 2.7 & 0.0 \\
\hline 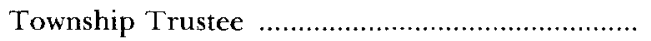 & 0.0 & 11.1 \\
\hline \multirow[t]{2}{*}{ 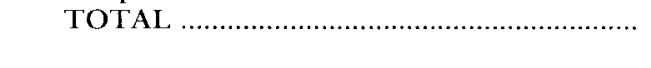 } & $100 \%$ & $100 \%$ \\
\hline & $(97)$ & $(22)$ \\
\hline
\end{tabular}

\section{Marital Status}

Though it has never been probed in relation to office aspirations, we believe that marital status may be a critical correlate, if not a causal factor of this type of political motivation since both the popular folklore and social statistics reveal marriage and a political career to be discordant. Given this, we should expect politicians with ambitions to show a lower rate of marriage (i.e., to be either single or divorced) than the unambitious. Furthermore, among the ambitious, the feeling of "having arrived" which one associates with static ambitions should mean that more of the politicians with this type of ambition would be married than those who are still climbing up the political ladder.

Our data bears out these suppositions. Marital status is strongly related to political ambitions in the manner that we have just outlined. The incidence of marriage is highest among the discretes, and lowest among the progressives, a pattern which buttresses our contention that the vicissitudes of pursuing a political career are generally inimical to marital intactness.

Further support for this line of thinking is provided by controlling for sex. The tendency for the aspirant for higher office to be single rather than married is even more characteristic of female than male officeholders. ${ }^{20}$ As mentioned earlier, combining marriage with a political career may prove less attractive or

20 Kirkpatrick's study of female delegates to the 1972 national convention also reported that the unmarried are more prone to be ambitious. Ibid., p. 417. 
more hazardous for females, because conventional sex role socialization processes do not support their persual of both types of careers; hence women with upward office aspirations are more likely to be unmarried.

\section{Age}

In Schlesinger's analysis, the point is made that one cannot explain variations in political ambitions without taking the fact of age into account. This is because, as Schlesinger notes, "the age cycle restricts a man's political chances. A man's reasonable expectations in one period of his life are unreasonable at another time." 21 Support for this proposition has been offered by several studies of political ambitions ${ }^{22}$ and is also corroborated by our data (Table 6). Revealing that advanced age is associated with diminished ambition, the data show that two-thirds of the officeholders with progressive ambitions, less than one-half with static, and only one-third with discrete ambitions are in the age bracket 35 to 50 years. In counterdistinction, the older one gets, the less the likelihood that one will have upward mobility political aspirations: only onefifth of the progressives are in the over 50 age bracket compared to one-third of those with static and one-half with discrete ambitions. So most of the older incumbents have static or discrete ambitions, and few harbor upward office goals. Like advanced age, youthfulness hinders the development of political ambitions. However, a greater proportion of those in the under 35 age category have progressive rather than static ambitions. Satisfaction with the office held is therefore largely a middle-age phenomenon.

Table 6. Age and Political Ambitions

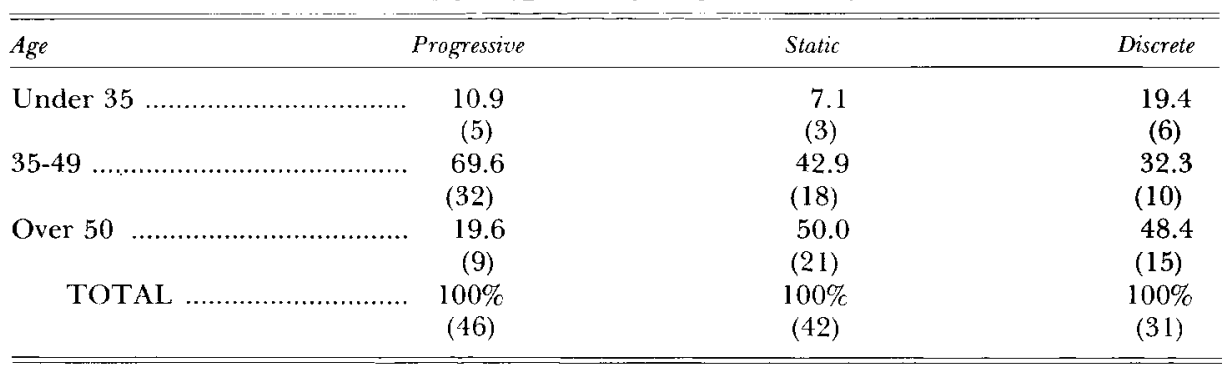

The preceding findings concerning the relationship between age and ambition are not applicable to all officeholders, but hold up only for men. The reason is that more older women (i.e., those over 50 years) than older men have discrete ambitions, and paradoxically, more younger women (i.e., those under 35 years) than younger men have progressive and static ambitions. ${ }^{23}$ In fact nearly three times as many younger women as men have progressive ambitions, and over twice as many have static ambitions. The tendency for an officeholder's aspirations to develop in middle age is therefore primarily a male phenomenon; women who aspire for a higher office are less likely to wait until

\footnotetext{
${ }^{21}$ Schlesinger, Ambition and Politics, p. 174.

22 Swinerton, "Ambitions and American State Executives"; Hain, "Age and Political Careers"; Prewitt and Nowlin, "Political Ambitions of Incumbent Politicians."

${ }^{23}$ Kirkpatrick's study also found that the most ambitious women delegates were under thirty. Kirkpatrick, New Presidential Elite, p. 417. And Lansing in a study of the voting patterns of black women showed that black women, particularly those who are younger, vote at a rate far higher than one would expect, and have outdistanced black men in their rate of increase in voting. So it seems that black women are highly politically motivated both at the level of voting and (as revealed by our data) aspiring for public office. For further elaboration of the voting patterns of black women see Marjorie Lansing, "The Voting Patterns of American Black Women," in A Portrait of Marginality, The Political Behavior of the American Woman, ed. Marianne Githens and Jewel L. Prestage (New York: David McKay, 1977), pp. 379-94.
} 
they are middle-aged, and those who pass 50 years are more prone than men to withdraw from politics.

\section{Socioeconomic Status}

It is almost an axiom of contemporary social science that human aspirations are a function of where one is located in the social structure. Hence educational and occupational status are investigated in practically all social science studies as if they held the key to understanding differences in social behavior. This is no less true of studies of political ambition. In fact, Schlesinger deemed occupation to be the only social background factor other than age that was in any way relevant to explaining diversity in political ambitions. ${ }^{24}$

When we examine occupations (i.e., extra-political occupation or occupation held before office was sought) we find that persons with progressive ambitions hold occupations slightly higher in status. (Table 7) However, the degree of occupational differentiation between officeholders with different ambitions is not as marked as might be expected. Furthermore, the data do not reveal any tendency for persons with particular types of occupations - e.g., lawyers or preachers ${ }^{25}$ - to be significantly more ambitious. Similar patterns

Table 7. Occupational Status and Political ambitions

\begin{tabular}{|c|c|c|c|}
\hline Occupational Status & Progressive & Static & Discrete \\
\hline 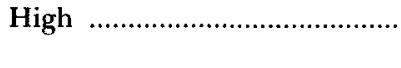 & $\begin{array}{l}71.7 \\
(33)\end{array}$ & $\begin{array}{l}57.1 \\
(24)\end{array}$ & $\begin{array}{l}61.3 \\
(19)\end{array}$ \\
\hline 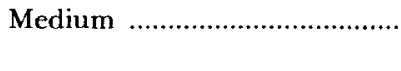 & $\begin{array}{c}15.2 \\
(7)\end{array}$ & $\begin{array}{c}16.6 \\
(7)\end{array}$ & $\begin{array}{c}25.8 \\
(8)\end{array}$ \\
\hline 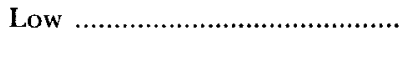 & $\begin{array}{c}13.1 \\
(6)\end{array}$ & $\begin{array}{l}26.3 \\
(11)\end{array}$ & $\begin{array}{c}12.9 \\
(4)\end{array}$ \\
\hline TOTAL ........................... & $\begin{array}{c}100 \% \\
(46)\end{array}$ & $\begin{array}{c}100 \% \\
(42)\end{array}$ & $\begin{array}{c}100 \% \\
(31)\end{array}$ \\
\hline
\end{tabular}

This measure of occupational status is based on collapsing the Alba Edwards scale of The Bureau of Census classification schema into a trichotomous index. See Alba Edwards, Index to Occupations, Alphabetical and Classified (Washington: Government Printing Office, 1915).

TABLE 8. Education and Political ambitions

\begin{tabular}{|c|c|c|c|}
\hline Educational Status & Progressive & Static & Discrete \\
\hline \multirow[t]{2}{*}{ 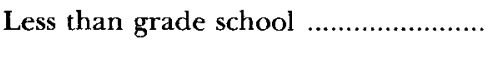 } & 0.0 & 0.0 & 0.0 \\
\hline & $(0)$ & $(0)$ & $(0)$ \\
\hline \multirow[t]{2}{*}{ Less than high school } & 0.0 & 9.5 & 3.3 \\
\hline & $(0)$ & (4) & (1) \\
\hline \multirow[t]{2}{*}{ High school graduate ........................... } & 10.9 & 19.2 & 19.4 \\
\hline & (5) & $(8)$ & (6) \\
\hline \multirow[t]{2}{*}{ Some college } & 26.1 & 21.4 & 25.8 \\
\hline & (12) & (9) & $(8)$ \\
\hline \multirow[t]{2}{*}{ 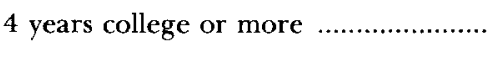 } & 63.0 & 49.9 & 51.5 \\
\hline & (29) & $(21)$ & (5) \\
\hline \multirow[t]{2}{*}{ TOTAL } & $100 \%$ & $100 \%$ & $100 \%$ \\
\hline & $(40)$ & $(42)$ & $(31)$ \\
\hline
\end{tabular}

${ }^{24}$ Occupation has an impact on political ambitions, according to Schlesinger, because political careers are often risky, temporary, and part-time, and those whose extra-political occupation can best adjust to these conditions will be more prone to seek office. Schlesinger, Ambition and Politics, pp. 7, 17.

25 The nonpredominance of lawyers among the ambitious is surprising because lawyers tend to make it easier in American politics than other professionals. The reason that we expected ministers in the church to be more ambitious is that historically they have functioned as de facto leaders of the black community. 
emerge when the educational status of the sample is linked to their political ambitions. (Table 8) In general the aspirant for higher office is more highly educated than his/her counterpart with static or discrete ambitions, a fact which suggests that higher education, like high occupational status, are advantages to the black aspirant for upward mobility in the political world.

\section{CONCLUSION}

This paper has endeavored to show that all black politicians are not alike in their motivations to seek office, and that these differences in office aspirations are not randomly distributed. Rather, they are a function to a large extent of the social and political backgrounds which unite and divide them.

Although there was some attenuation based on sex, the main distinctions which emerged were not between officeholders with static and progressive ambitions, but between these two groups and those with discrete ambitions. The progressives and statics differ in that the former are more likely to be younger, more prone to ticket-splitting, more likely to remain unmarried, and of slightly higher socioeconomic status. These characteristics - age, ticketsplitting, marital status, and education - are also the source of even more marked divergence between progressives and statics on the one hand and discretes on the other. However, in addition the nonambitious are more likely to have been recruited by the community rather than by other governmental officials, to have held fewer offices in the past, and to hold offices that are less politically significant and financially remunerative.

These differences in social and political backgrounds among the various ambition categories lead us to believe that the reason why some blacks are more eager to pursue political careers is because they have the social credentials such as education - the political backing, and the political experience to be successful at officeholding. In other words, there seems to be a selection mechanism at work which is either perceived by officeholders, and causes "potential failures" or "losers" to self-select out of the public domain, thereby fulfilling Carl Friedrick's rule of anticipated reactions, ${ }^{26}$ or one which deliberately screens out candidates who fail to fulfill the requirements for official advancement. ${ }^{27}$ Whether those with the necessary "credentials" are able to realize their office goals is a question that can only be answered by data gathered over time.

${ }^{26}$ Carl J. Friedrich, Constitutional Government and Democracy (New York: Ginn, 1937), pp. 16-18; and his Man and His Government (New York: McGraw-Hill, 1963), Chapter 11.

${ }^{27}$ For a discussion of how selectorates can determine the composition of political elites see Robert Putnam, The Comparative Study of Political Elites (Englewood Cliffs: Prentice Hall, 1976), pp. 52-65. 